\title{
BURROWING OWLS
}

\section{A. McPherson, Saskatoon}

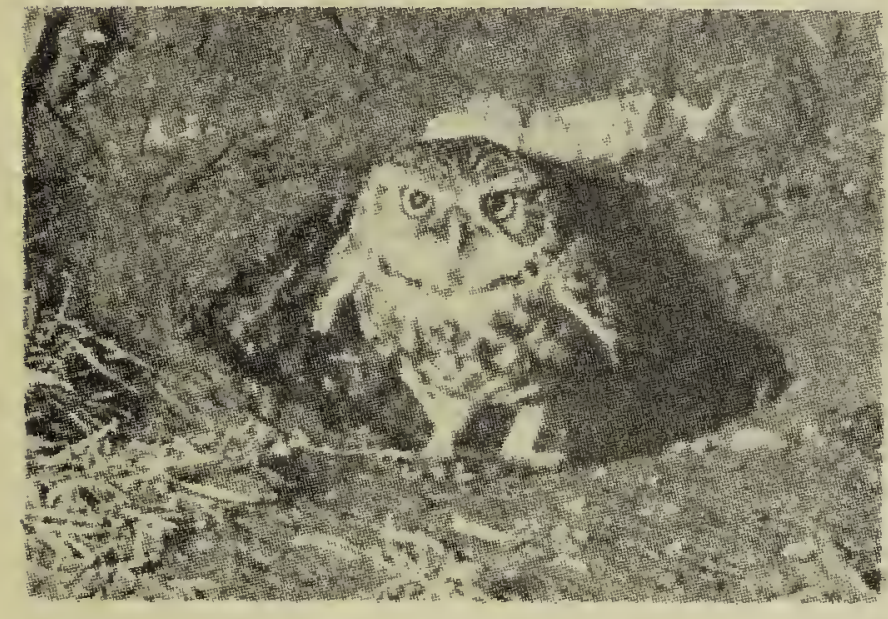

WHILE driving north of the city of Saskatoon on July 18th last, I noticed a Burrowing Owl perched on a telephone pole. The following day I went back and investigated the area and found the owl's burrow.

I was very keen to capture them for banding purposes and thought I might be able to get the young before they were on the wing. However, I was late for that so decided to take up two traps to try my luck. There were seven in this family. I took a single Potter's trap and an ordinary lead-in trap.

The owls had two openings from their burrow so I decided to set one trap at each entrance. The traps did not concern the owls in the least, the day I placed them there-just used them for roosting perches.

The first one I captured was in an unusual way. Going up to the traps one evening I flushed the owls and a Kingbird came swooping down at one, and kept right after it until it was obliged to fly into the Fox-tail Grass. This happened about fifty feet from where I stood, so I ran across and picked up the owl and banded it. I hoped the Kingbird would be around every time I came up, to oblige me.

I banded two more, but they were both captured in the lead-in trap. That was on August 5th and 6th. They left the burrow about August 10 th for good.

Bird Banding Notes, issued in August, 1950, shows that 1,001 Burrowing Owls have been banded from 1942 to 1949.

Another rare bird that I banded this year was a Turkey Vulture, captured at Prud'homme, Saskatchewan, and brought here for identification, August 10th, 1951.

\section{Prairie Falcon at Saskatoon}

\section{Stuart P. Jordan}

NOTICE that under an article written by Stuart Houston about Red Crossbills you asked if any other localities were visited this summer and if so, were they nesting.

On June 24, there was a family of Red Crossbills in our front yard. The young almost seemed able to fend for themselves, so it is difficult to say if they were raised in this vicinity or not.

I positively identified a Prairie Falcon in Saskatoon along the river bank on December 11, 1951. The main identifying features were its size and the fact that "the underwing surface shows a decided dark patch formed of the smoky auxiliaries" (Taverner). Taverner also says that this falcon is noted for preying on domestic pigeons, and there is a sizable flock in the vicinity in which it was seen. This is the third successive year that I have seen a falcon under the 25th Street bridge at this time of year. Its length of stay varies each year, the first being the longest-December 17 to March 15-this year being the shortest, December 8 to December 23. Wouldn't it be interesting to learn if the Falcon I saw in Regina on December 25 was the same one that haunted the bridge in Saskatoon?

Large flocks of Bohemian Waxwings have been in the vicinity of Saskatoon for the past month. The berry crop was a bountiful one this fall and these handsome birds are reaping their fill. 